\title{
A Review of Research on the Use of Higher Order Thinking Skills to Teach Writing
}

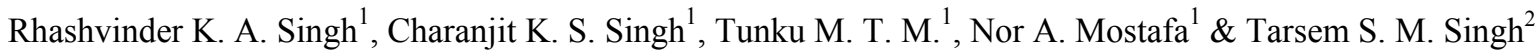 \\ ${ }^{1}$ Faculty of Languages and Communication, English Language and Literature Department, Sultan Idris \\ Education University, Malaysia \\ ${ }^{2}$ IPG Kampus Tuanku Bainun, Bukit Mertajam, Pulau Pinang, Malaysia \\ Correspondence: Rhashvinder K. A. Singh, Faculty of Languages and Communication, English Language and \\ Literature Department, Sultan Idris Education University, Malaysia. E-mail: rashvyne@gmail.com
}

Received: July 12, 2017 Accepted: September 13, 2017 Online Published: October 25, 2017

doi:10.5539/ijel.v8n1p86 URL: http://doi.org/10.5539/ijel.v8n1p86

\begin{abstract}
This paper reviews the literature on the teaching of higher order thinking skills to teach writing in Malaysian context. The issues pertaining the usage of higher order thinking skills to teach writing are also discussed in this paper. ESL teachers are only trained to ask Higher Order Thinking Skills questions where the teaching of writing is concerned but most of them have very little knowledge on implementing the pedagogical knowledge of higher order thinking skills. Despite having multiples of programs to help teachers to infuse higher order thinking skills to teach writing, past studies have reported that teachers were not prepared to teach higher order thinking skills in their own classrooms. Hence, this paper further analyses the need to investigate the issues that are related on the usage of higher order thinking skills to the teaching of writing which needs immediate attention.
\end{abstract}

Keywords: higher order thinking skills, writing, weak ESL learners, ESL teachers, pedagogical knowledge

\section{Introduction}

Giving English the status of a second language, it is deemed to be taught in all schools. To enable the students to use the language in everyday life for a handful or purposes, students are taught the English language subject. With globalization, all Malaysian will need to be proficient in English medium for communicating with people from other countries. According to the Malaysia Education Blueprint 2015-2025, The Ministry of Education Malaysia governs all national education-related matters from preschool to higher-level education. The aims are to provide all Malaysian citizens with equal access to quality education that form highly-skilled, knowledgeable, and united Malaysians. In order to be a highly skilled and knowledgeable citizen, it will require one to think critically and creatively.

Based on the Malaysia Education Blueprint 2015-2025, the Ministry of Education Malaysia aims to provide all Malaysian citizens with equal access to quality education to form students that are highly-skilled and knowledgeable. In order to be a highly skilled and knowledgeable citizen, it will require one to think critically and creatively. There are more reformed efforts taken to make Malaysia a country who has a well-balanced citizens. This move is more evident when National Education Philosophy (NEP) which was documented in 1987 clearly draws attention on how the education system of Malaysia is working to mold students in becoming capable of achieving a high level of self well-being to contribute to the betterment of the nation, family as well as the society. Following is the extract of the NEP:

"Education in Malaysia is an ongoing effort towards further developing the potential of individuals in a holistic and integrated manner, in order to produce individuals who are intellectually, spiritually, emotionally and physically, balanced and harmoniously, based on a firm belief in and devotion to God. Such an effort is designed to produce Malaysian citizens who are knowledgeable and competent, who possess high moral standards and who are responsible and capable of achieving a high level of personal well-being to contribute to the betterment of the nation, family and society."

This extract shows that Malaysian has the ambition to produce educated Malaysians that are all-rounders. The NEP enunciates on Malaysian that are persistent to acquire and exercise their knowledge to others besides than just themselves. The NEP also unwaveringly make emphatic on people who are savvy not only in the sense of 
knowledge but as well as certain skills that enables them to contribute for the flowering of nation. One of the most underlined aspect of NEP is intellectual. Intellectual is an aspect that covers the cognitive knowledge. Cognitive here not only includes the ability to think logically but being able to manipulate the cognitive level to enable one to think critically and creatively which will help in problem solving.

One of the problems that teachers face is, entering a huge class with a variety of students. Some may have limited English proficiency, some may come from different backgrounds, with multiple emotions about the school experience and some are also with different passions or interests. Having to face all these challenges, teachers have to foster critical and creative thinking in their students. Teachers are put in charge to create students that are built to take up world challenges. Students need to be aware of what they know, and what they don't know, and to use this awareness to build their knowledge. They need to learn how to take data they encounter and transform it into their own knowledge.

\section{Literature Review}

\subsection{The Nature of Higher Order Thinking Skills}

Higher order thinking skills include critical thinking, problem solving, decision making, and creative thinking (Lewis \& Smith, 1993). According to Dewey (1933), thinking does not occur spontaneously but must be "evoked" by "problems and questions" or by "some perplexity, confusion or doubt." It is important to teach students to think about their own thinking processes (Kauchak \& Eggen, 1998). Higher order thinking skills include critical, logical, reflective, metacognitive, and creative thinking.

According to King (1997), the ability of higher order thinking skills are activated when individuals encounter unfamiliar problems, uncertainties, questions, or dilemmas. When this skills are nurtured and well developed, one can perform better during explanations and making decisions as well as grow their intellectual skills. Development of higher order thinking skills, relies on their lower level thinking skills thus making higher order thinking skills grounded with lower level thinking skills. To be able to think critically, prior knowledge of subject matter content is necessary. According to King et al. (1997) as well appropriate teaching strategies and learning environments facilitate their growth as do student persistence, self-monitoring, and open-minded, flexible attitudes.

This is not the scenario that is happening in Malaysia. Students are having trouble to use their thinking skills. According to Othman (2014), the Malaysia Education Blueprint states that "Education plays a central role in any country's pursuits of economic growth and national development. There is no better predictor of a nation's future than what is currently happening in its classrooms. Othman (2014), reviewed that are we clear of what our teachers are supposed to do in the classrooms which then implies to the current problem at hand which is, are teachers unable to create students that can think critically and creatively in the classrooms as well as in real life situations.

One of the scenario that is happening in Malaysia is that, teachers are only trained to ask HOTS question but most of them have very little knowledge on the pedagogical knowledge of HOTS (Rajendran, 1999). The best way to enable student to use HOTS in their everyday life is when teachers in schools have a good pedagogical knowledge on HOTS, truly understands HOTS then transfuse this knowledge in everyday lesson so that it will be easier to see the changes in the student's thinking skill (Rajendran, 1999).

However, when students are writing, they are unable to produce a good write up especially with good thinking skills. They are unable to think creatively and critically. According to the Malaysia Education Blueprint 2015-2025, thinking skill is also one of the six aspirations that students of Malaysia should have. It further emphasizes that, every child will learn how to continue acquiring knowledge throughout their lives, to be able to connect different pieces of knowledge, and to create a new knowledge. Every child will master a range of important cognitive skills including critical thinking, reasoning, creative thinking, and innovation. Therefore in other words, this is a problem in which the students are unable to apply critical thinking outside familiar academic contexts.

One of the effective ways of teaching higher order thinking skills will be when there's infusion on critical and creative thinking in the activities prepared. The researcher believes that there are activities that are prepared to teach the learners on how to be able to think critically as well as analytically. Serious efforts should be taken to ensure that the implementation of higher order thinking skills in the classrooms so that it would result in students who can use higher order thinking skillfully to solve problems. Despite having multiples of programs to help teachers to infuse higher order thinking skills into teaching, Rajendran (1999) in his research discovered that teachers were not prepared to teach higher order thinking skills through infusion in their own classrooms. He 
also stated that most of the teachers lacked the skills to construct higher order thinking skills related content knowledge.

Being able to use higher order thinking skills is vital because without conscious attempt one can build up more from what one have learned before. Since higher order thinking skills requires one to form connections between what one had learned with what one is going to learn, it is important to develop skills to assist this level of thinking. To establish a connection from what they have learned and with a newly required knowledge they will have to be able to think critically. Although thinking is a conscious process and it is undeniably the core of learning, being able to use higher order thinking skills for instance analyzing, applying, synthesizing and evaluating needs to be emphasized in teaching and learning a second language because language learning is similar to skill learning. Only this will then be evaluated as making sense of what they have learn.

It is undeniable that the ability to think effectively is very important in today's world especially when it becomes more complex and sophisticated. It has also become unquestionable that being able to think using the Higher-order thinking skills are one of the skills that one need to master. With the modernization and the socioeconomic changes that happen very swiftly day by day, people are more exposed to solving various problems and having to take numerous decisions. Thus, students need to exercise their thinking skills in making the right choices.

Apart from that, in the education field it is equally important to have students who also acts as the new generation of the country to be able to think and become a more critical and analytical thinker. Not just that, in Malaysia, the notion of teaching higher-order thinking skills is not a new idea in its education system. It has been decades since the ministry of education try to introduce and bring about changes to the Malaysian classrooms through various programs. As a matter of fact, there are already some of the elements of critical and creative thinking skills that have been visible in most of the curriculum specification across all the subjects.

Despite having a systematic education system in Malaysia, one of the major problems that teachers face is similar to what John Dewey has once said,

"If he (student) cannot devise his own solution (not of course in isolation, but in correspondence with the teacher and other pupils) and find his own way out he will not learn, not even if he can recite some correct answer with one hundred per cent accuracy. We can and do supply readymade "ideas" by the thousands we do not usually take much pains to see that the one learning engages in significant situations where his own activities generate, support, and clinch ideas - that is, perceived meanings or connections."

This actually reflects to the ability to think. Higher-level thinking is a significant goal of our education system today. Students should be challenged from rote memorization to deeper understanding of content. Brookhart (2010) identifies definitions of higher-order thinking as falling into three categories: (1) those that define higher-order thinking in terms of transfer, (2) those that define it in terms of critical thinking, and (3) those that define it in terms of problem solving. While learning for recall requires thinking, the higher-order thinking is in "transfer". This is similar to having the student acquire the knowledge and skill then applying it. It is this kind of thinking, according to Brookhart (2010) that applies to life outside of school where thinking is characterized by "a series of transfer opportunities (rather) than as a series of recall assignments to be done". The critical thinking category includes definitions that refer to "reasonable, reflective thinking that is focused on deciding what to believe or do" (Norris \& Ennis, 1989) and "artful thinking", which includes reasoning, questioning and investigating, observing and describing, comparing and connecting, finding complexity, and exploring viewpoints (Barahal, 2008).

Ministry of Education has worked ways to improve on HOT in Malaysia. One of the major projects is i-THINK in which it is used to help develop thinking skills in all Malaysian schools. The Malaysian Government and Agensi Inovasi Malaysia (AIM) conjointly created the i-THINK project to prepare Malaysia's next generation of innovators to think critically and be adaptable in preparation for the future.

Using thinking skills enables students to write effectively. This is so because using thinking skills students are able to generate idea critically and analytically. This is supported by Yee et al. (2013), students who are able to use higher order thinking skills are capable to find new ways to solve their daily problems and make appropriate decisions. Piaget (1970) and Vygotsky (1978) stated that children are active agent of learning as they construct their own understanding of the world (cited in Jarvis, 2005). When students are able to construct their own thinking and understanding, they are able to generate ideas for writing. This is also braced by Jarvis (2005) in which he mentioned the role of teacher is to facilitate learning situations so the children can find things out for themselves. Through this active process, children can construct their understanding and consequently develop higher order thinking skills. 
The Malaysia Education Development Plan (PPPM) 2013-2025 intends at creating knowledgeable students who are able to think creatively and critically to compete at the international level. Aside from that, according to Malaysia Education Blueprint 2015-2025, thinking skill is also one of the six aspirations that students of Malaysia should possess. This implies that thinking skills is important in shaping students to fit the21st century.

During this newfangled years, the application and construction of high-order thinking skills are very highly esteemed in teaching and learning. A number of influential psychologists and educationists supported the importance of developing thinking skills in learning (Jarvis, 2005). For example,

"The advent of Information Age has made the development of problem solving, critical thinking and higher order thinking skills crucial to future success." (Adawati, 2014).

Keeping this in mind, it is undeniable that teachers play an important role to school students to be competent in thinking at a higher level especially to congregate with the obstacles in the future. Alongside with that, teachers should also equip students with the knowledge to meet the career world later in the future. Hence, this studies aims to assist teachers in the integration of higher order thinking skills in teaching of writing.

\section{Methodology}

This paper seeks to present information on the issues related to HOTs based on the literature review of previous research by other scholars. By using a document analysis technique, issues and findings reviewed from scholars discussing about HOTs will be presented in the form of table in this paper as shown below.

Table 1. Information related with the issue discussed in this paper

\begin{tabular}{llll}
\hline References & Research title & \\
\hline Kauchak \& Eggen & $\begin{array}{l}\text { Effective teaching to reduce } \\
\text { (1998) }\end{array}$ & $\begin{array}{l}\text { educational failure } \\
\text { King, F. J., Rohani, F., \& }\end{array}$ & Higher Order Thinking Skills \\
Goodson, L. (1997) & &
\end{tabular}

Using questions to develop students' higher-order thinking skills: a primary English teacher's beliefs and practices

Yee, M. H., Widad, B. O., Jailani, B. Md Y., Tee, T. K., Razali, B. H., \& Mimi, M. B. M. (2013).

Shukla, D. (2016)

Tanujaya, B. (2016)
The Level of Marzano Higher Order Thinking Skills among Technical Education Students

Student's Perceived Level and Teachers' Teaching Strategies of Higher Order Thinking Skills, A Institutions in Thailand

Development of an Instrument to Measure Higher Order Thinking Skills in Senior High School Mathematics Instruction Study on Higher Educational
Issue related/ findings

- It is important to teach students to think about their own thinking processes.

- Higher order thinking skills include critical, logical, reflective, metacognitive, and creative thinking.

- HOTs activated when individuals encounter unfamiliar problems, uncertainties, questions, or dilemmas

- Appropriate teaching strategies and learning environments facilitate their growth as do student persistence, self-monitoring, and open-minded, flexible attitudes.

- Lower-order thinking (LOT) is usually considered by the action of recalling information, understanding the information and applying the knowledge to certain context

- Higher order thinking skills encompasses a more complex cognitive means as it requires "conceiving, manipulating, and dealing abstractly with ideas

- There are 13 higher order thinking skills, namely comparing, classifying, inducing, deducing, error analysis, constructing supporting, analysing perspectives, abstracting, decision making, investigation, problem solving, experimental inquiry, and invention

- Higher order thinking skills allow students to see the concept holistically as well as result in developing an effective thinker's attitude

- Teachers' professional development especially in the field of teaching experience and qualification give an impact on the use of higher order thinking skill in a class

- It has been the responsibility of the education system to inculcate students with higher order thinking skills and give importance to using teaching strategies which focuses on analysing, interpreting, reasoning, synthesizing and creating

- Low skill levels in thinking may be caused by teacher's lack of attention to such thinking skills.

- Students with higher order thinking skills are able to learn, improve their performance, and reduce their weaknesses

- Thinking skills among students especially at every level of education is deteriorating. HOTS is an essential aspect of teaching and learning.

- $\quad$ Students are unable to structure thinking skills.

- Theoretical review for building Hots among students are conceptual definitions, building operational definitions, defining constructs, dimensions, and indicators. 


\begin{tabular}{|c|c|c|}
\hline Schulz (2016) & $\begin{array}{l}\text { Teachers' Understandings of Critical } \\
\text { and Higher Order Thinking and What } \\
\text { This Means for Their Teaching and } \\
\text { Assessments. }\end{array}$ & $\begin{array}{l}\text { - Critical thinking was classified as a higher order thinking skill in this } \\
\text { research. } \\
\text { - Critical thinking, metacognitive thinking, productive thinking, creative } \\
\text { thinking, complex thinking, deep thinking, and logical thinking are } \\
\text { skills falls under the category of higher order thinking skills. } \\
\text { Thinking should be taught no matter in what subject is taught and this } \\
\text { is important because teachers are in charge of creating students that are } \\
\text { able to be independent thinking pupil. } \\
\text { Teachers also believe that students with some issues like weak } \\
\text { learners, low socio-economic status as well as trouble in learning } \\
\text { might find it difficult to perform higher order thinking skills. } \\
\text { Teachers are in confusion on how to include higher order thinking skill } \\
\text { with the content subject because they are having troubles in explaining } \\
\text { about higher order thinking skills and ways to assess them. }\end{array}$ \\
\hline $\begin{array}{l}\text { Budsankom, P., Tatsirin, } \\
\text { S., Suntorapot, D., \& } \\
\text { Jariya, C. (2015). }\end{array}$ & $\begin{array}{l}\text { Factors affecting higher order thinking } \\
\text { skills of students: A meta-analytic } \\
\text { structural equation modeling study }\end{array}$ & $\begin{array}{l}\text { - Thinking skills can be categorized into three type namely critical } \\
\text { thinking, creative thinking and analytical thinking. } \\
\text { - Students who are able to use higher order thinking skills are able to } \\
\text { create new knowledge from the knowledge they have to make a logical } \\
\text { explanation } \\
\text { some of the factors that may influence the students thinking skills are } \\
\text { classroom environment, family background, psychological condition } \\
\text { as well as the student's intelligence }\end{array}$ \\
\hline Raiyan \& Tilchin (2015) & $\begin{array}{l}\text { Higher-Order Thinking Development } \\
\text { through Adaptive Problem-based } \\
\text { Learning }\end{array}$ & $\begin{array}{l}\text { - } \\
\text { - } \\
\text { - Students should be equipped with two other skills which are being able } \\
\text { to think analytically and creatively as it allows students to choose the } \\
\text { best alternative } \\
\text { Being able to think analytically ensures students to compare and } \\
\text { contrast as well as evaluate. Being able to think creatively also allows } \\
\text { students to produce a new set of thinking. }\end{array}$ \\
\hline $\begin{array}{l}\text { Soo, Nor Haniza, Rohani } \\
\text { \& Siti Nuur-ila Mat. } \\
(2015) \text {. }\end{array}$ & $\begin{array}{l}\text { Innovating with HOTS for the ESL } \\
\text { Reading Class }\end{array}$ & $\begin{array}{l}\text { - Some of the teachers are also having bad impression towards } \\
\text { incorporating thinking skills into English language lesson. } \\
\text { Teachers believe that is it difficult to incorporate thinking skills into a } \\
\text { language class. To these teachers, thinking skills are often associated } \\
\text { with science and mathematical subjects. } \\
\text { Teachers have been found to lack creativity in innovating their lessons, } \\
\text { then resulted in students being passive }\end{array}$ \\
\hline
\end{tabular}

\section{Discussion}

The theoretical framework constructed depicts the relationship of using cognitive theory called the Schema Theory. Schema Theory is often related to mental development. According to Fushan (2014), schema refers to a collection of knowledge often associated with a concept and it contains background knowledge of content, text structure and hierarchical organization of the text. Using this as a guide, students need to possess and activate their previous schemata stored in their long-term memory as well as obtain new knowledge to write a good essay during the writing process. Schemata supply the necessary knowledge of phrases, content and organization forms, which have much influence on writing planning, revising and editing process (Fushan, 2014).

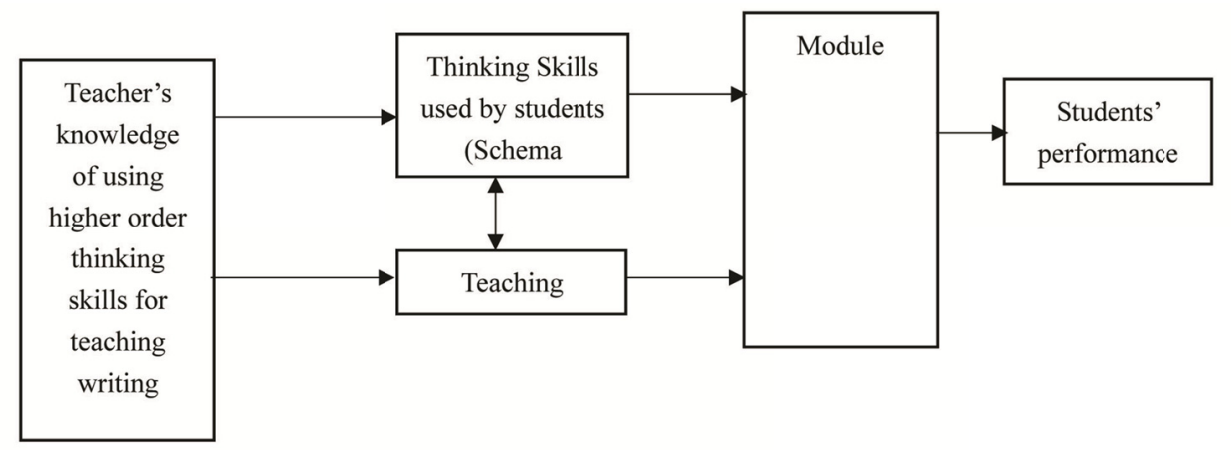

Figure 1. Theoretical and conceptual framework 
Figure 1 shows that the teacher's content knowledge of higher order thinking skills for teaching writing affect her instructional strategies which are achieved through the interaction with the students and the module used. The teacher's knowledge of using higher order thinking skills in the class will influence the thinking skills used by the students in the class. The teacher will use the knowledge of the thinking skills she possess and teach this knowledge to the students. The accomplishment of the students depends fully on the teacher's knowledge. However, by using the module, students will be able to master different types of thinking skills provided in the module so that the students could use various type of thinking skills.

It is undeniable that one of the 21 st century component that students are required to learn is the ability to use higher order thinking skill with ease. With the help of theories, it allows teachers to have a framework that enables them to scaffold ways to teach thinking skills in a more systematic way. Being able to use higher order thinking skills puts the students on a whole new level. This is because being able to do higher order thinking sills is much more than just memorizing facts as students have to understand the facts then use this fact to connect this fact to other knowledge.

There are some ways to encourage higher order thinking skills among students. Some of the ways that teacher can implement HOTS is through questioning. Copious studies have proven that higher level questions lead to higher cognitive processes (Baston, 1981; McKenzie, 1972; Taba, 1966). When students are able to question the output given by the teacher, it shows that students are thinking. Not only that, teachers should create room for students to ask questions instead of restricting them or shutting doors for them when they have qualms. Teacher should ensure that the teacher doesn't give negative reaction to the students when they have questions same goes to their peers. Teachers should have an open room discussion in which it allows students to think creatively. If students have questions and they seem unsure to answer them, teachers can guide them to answer it themselves.

Teachers can also adopt a good thinking skill among the students is by teaching them the process of how to create connections between concepts. Willingham (2007) stated in his research that, the processes of thinking are intertwined with the content of thought or known as the main knowledge. This engages the students with the knowledge that they possess with the new knowledge that they are going to learn. When the students are able to do this, it gives them better understanding of a concept.

Another strategy that can help students in thinking critically is by teaching them to infer. Teacher should allow students to use real world problems. For example, have the students talk about an incident that is currently famous or trending.

Receiving an aid to teach critical thinking is also another way to help to think critically. For example to include graphic organizer. Using diagrams enables students to make connections and develop relationships between ideas. Using diagrams also shapes the thinking into a more ordered and systematic way of thinking.

Teachers can infuse critical thinking among the students. When students are doing critical thinking, they are required to imagine and strategize what they are thinking. Being able to use critical thinking allows students to process and understand information clearer. Critical thinking also permits students to think out of the box hence being able to comprehend a new knowledge in several different perspective.

It is essential to teach students to elaborate their answer. When students elaborate their answers, they have to know the concepts well and try to elaborate it from the meaning that they can decipher from it. This will also encourage them to talk about what they understand from what has been taught to them. Instead of a yes or no answers, more detailed answers should be required from the students.

The best strategy to teach higher order thinking skill is by letting the students know about the relationship between question and answer. Teachers can do this by giving a question that involves a bigger picture to the students. Students should find answers from this question using all means possible. From this questions students will have to rely on previous knowledge to answer a new question. This strategy is known to promote higher-order thinking because students are more alert between the bridges made from the previous knowledge to the new one.

All of the teaching strategy is well supported by Johnson \& Thomas (1992) whom also presented four general principles concerning to successful learning strategies:

1) Assist in students' classification of knowledge to make it in a more systematic way so it is easier to apprehend a knowledge and teachers can use media, visual and aid maps which can visually exemplify concepts and relationships.

2) Construct new knowledge from the knowledge that students already possess and then turn it as an aid to help students understand the difference between a new knowledge and previous knowledge. 
3) Teachers assist students by teaching them problem-solving methods and choosing strategies suitable for methodologies and smooth the progress of thoughts about procedures.

4) Encourage deep thinking via amalgamation; for instance doing thinking in a pair or in groups.

\section{Conclusion}

This study reviews and highlights the importance of HOTs to assist students to think critically and creatively. Higher Order thinking skills enables student to think in a more complex way in which the student is able to control it. Being able to think creative and critically enables students to be prepared to face the real world situation. Teaching of Higher-order Thinking Skills (HOTS) has its own challenges and these challenges deserve immediate attention. The strategies that the teachers use will assist the students to strategize their thinking according to the situation at hand. Instead of just knowing the knowledge, students should manipulate the knowledge and turn it into something new and meaningful.

There are a number of studies done for the implementation of Higher Order Thinking Skills in a classroom however most of them are not related to a language classroom. Therefore, it is necessary to produce with research pertaining the usage of Higher Order Thinking Skills in a language classroom. Therefore, it can be concluded that, being able to use higher order thinking skills played a very important role in the English language classroom. Students with no English experience outside classroom need strategies such as higher order thinking skills to increase their thinking skills in their daily life. Using writing as a tool to use higher order thinking skills to ESL young learners is a very good and interesting approach.

\section{Limitation of Study}

The findings of this study will be based on the responses and performances of the teachers and students during the selected learning units only, without considering those in other lessons. Thus, it does not reflect the outcomes of the whole learning unit.

\section{Acknowledgement}

We acknowledge with great appreciation the kind gesture of the Malaysian Ministry of Higher Education for providing us the Fundamental Research Grant Scheme (Coded: FRGS/KPT 2016-0068-107-02: FRGS/1/2016/SS109/UPSI/02/15). Equally, we would like to express our gratitude to all the participating teachers for their willingness to be observed and to share their classroom practices.

\section{References}

Adawati, H. S. (2014). Exploring teachers' experiences on integration of higher order thinking skills (HOTS) in teaching of science. Masters thesis. Universiti Malaysia Sarawak, UNIMAS.

Batson, A. D. (1981). Questioning: A reading/thinking foundation for the gifted. Paper presented at the Annual Meeting of the Southwest Regional Conference of the International Reading Association, San Antonio, Texas, 29-31 Jan. (ERIC Document Reproduction Service No. ED 201 999.)

Brookhart, S. (2010). How to Assess Higher Order Thinking Skills in Your Classroom, ASCD. Retrieved from http://www.ascd.org/Publications/Books/Overview/How-to-Assess-Higher-Order-Thinking-Skills-in-YourClassroom.aspx

Budsankom, P., Tatsirin, S., Suntorapot, D., \& Jariya, C. (2015). Factors affecting higher order thinking skills of students: A meta-analytic structural equation modeling study. Educational Research \& Reviews, 10, 2639-2652. https://doi.org/10.5897/ERR2015.2371

Dewey, J. (1933). How we think: A restatement of the relation of reflective thinking to the educative process. Boston: D. C. Heath and Company.

Jarvis, M. (2005). The psychology of effective teaching and learning. Cheltenham, UK: Nelson Thornes.

Johnson, S. D., \& Thomas, R. G. (1992). Technology Education and the Cognitive Revolution. The Technology Teacher. Technology Teacher, 51(4), 7-12.

Kauchak, D., \& Eggen, P. (1998). Learning and Teaching: Research-based Methods (3rd ed.). Boston: Allyn and Bacon.

King, F. J., Rohani, F., \& Goodson, L. (1997). State wide assessment of listening and verbal communication skills, information literacy skills, and problem-solving skills. Tallahassee: Florida State University.

King. (1997). State wide assessment of listening and verbal communication skills, information literacy skills, and problem-solving skills. Tallahassee: Florida State University. 
Lewis, A., \& Smith, D. (1993). Defining higher order thinking. Theory into Practice, 32(3), 131-137. https://doi.org/10.1080/00405849309543588

McKenzie, G. R. (1972). Some effects of frequent quizzes on inferential thinking. American Educational Research Journal, 9(2), 231-240. https://doi.org/10.3102/00028312009002231

Othman, N. (2014). Exploring Leadership Characteristics in Innovative Teachers for Innovative Students. 7th International Conference of Education Psychological Capital in Education and Innovation.

Piaget, J. (1970). Science of education and the psychology of the child. New York: Viking

Raiyn, J., \& Oleg, T. (2015). Higher-Order Thinking Development through Adaptive Problem-based Learning.

Rajendran, N. (1999). Teaching Higher Order Thinking Skills in Language Classrooms: the Need for Transformational of Teaching Practice. (PhD. Dissertation, Michigan State University).

Saido, G. M., Saedah, S., Abu, B. B. N., \& Omed, S. A. A. (2015). Higher Order Thinking Skills Among Secondary School Students in Science Learning. The Malaysian Online Journal of Educational Science.

Schulz. (2016). Teachers' Understandings of Critical and Higher Order Thinking and What This Means for Their Teaching and Assessments. Memorial University of Newfoundland.

Shukla, D. (2016). Student's Perceived Level and Teachers' Teaching Strategies of Higher Order Thinking Skills, A Study on Higher Educational Institutions in Thailand. Department of Business Administration, St. Theresa International College, Thailand.

Soo, N., Haniza, R., \& Siti Nuur-ila, M. (2015). Innovating with HOTS for the ESL Reading Class. Canadian Center of Science and Education

Sun, F. S. (2014). The Application of Schema Theory in Teaching College English Writing. Academy publisher. Finland. https://doi.org/10.4304/tpls.4.7.1476-1482

Taba, H. (1966). Teaching strategies and cognitive functioning in elementary school children. Cooperative Research Project No. 2404. San Francisco State College.

Tanujaya, B. (2016). Development of an Instrument to Measure Higher Order Thinking Skills in Senior High School Mathematics Instruction. Department of Mathematics Education. University of Papua.

Thompson, T. (2008). Mathematics Teachers' Interpretation of Higher-Order Thinking in Bloom's Taxonomy. International Electronic Journal of Mathematics Education, 3(2), 96-109.

Vygotsky, L. S. (1978). Mind in Society: the Development of Higher Psychological Processes. Cambridge, MA: Harvard University Press.

Willingham, D. T. (2007). Cognition: The thinking animal (3rd ed.). Upper Saddle River, NJ: Pearson/Allyn \& Bacon.

Yee, M. H., Widad, B. O., Jailani, B. Md Y., Tee, T. K., Razali, B. H., \& Mohamad, M. M. B. (2013). The Level of Marzano Higher Order Thinking Skills among Technical Education Students. International Journal of Social Science and Humanity, 1(1), 121-125.

\section{Copyrights}

Copyright for this article is retained by the author(s), with first publication rights granted to the journal.

This is an open-access article distributed under the terms and conditions of the Creative Commons Attribution license (http://creativecommons.org/licenses/by/4.0/). 